\title{
BóRIS SCHNAIDERMAN: TURBILHÃO E SEMENTE ${ }^{1}$
}

http://dx.doi.org/10.11606/issn.2237-1184.v0i26p84-90

Regina Pontieri²

Universidade de São Paulo (USP)

\section{RESUMO}

Este texto é uma homenagem a Boris Schnaiderman apresentada em evento comemorativo de seus noventa anos. A autora, ex-aluna do homenageado, procura lhe esboçar um breve perfil, cruzando os fios das leituras de alguns de seus livros com aqueles advindos de sua convivência acadêmica. Procura, sobretudo, dar testemunho da relevância da atuação de Schnaiderman, em quem as múltiplas tarefas - de escritor, jornalista, professor, pesquisador - sempre estiveram reunidas por uma rigorosa exigência de cunho ético.

\section{ABSTRACT}

This tribute to Boris Schnaiderman was previously presented in a celebration of his 90 years. The author, that was his former student, tried to sketch a brief profile by weaving lines extracted from some of his writings and also of their close academic approch. The special aim was to testify the relevant importance of Schnaiderman's multiple tasks: writer, journalist, professor, researcher - acts that were always guided by a rigorous ethical requirement.
PALAVRAS-CHAVE:

Boris Schnaiderman; Homenagem; Literatura russa; Cultura russa.

\section{KEYWORDS:}

Boris Schnaiderman; celebration; Russian literature; Russian culture.

\footnotetext{
${ }^{1}$ Este texto foi lido durante o evento em homenagem aos noventa anos de Boris Schnaiderman, em 2007, evento organizado pela Área de Língua e Literatura Russas da FFLCH/USP.

2 Professora aposentada do Departamento de Teoria Literária e Literatura Comparada - FFLCHUSP
} 
omeço esta homenagem a Boris Schnaiderman prevenindo que se trata apenas do testemunho de uma ex-aluna que tem sido também, e principalmente, uma grande admiradora, para quem o professor Boris sempre foi o que se chama Mestre, com M maiúsculo: aquele que ensina, para além dos conteúdos intelectuais, a preservação dos mais altos valores humanos. E ensina com o seu próprio exemplo: dignidade, honestidade, tolerância, enfim esse essencial que, infelizmente, nem sempre se encontra. Antes de conhecer o professor, conheci o ficcionista Boris Schnaiderman. Em 68, quando eu me preparava para o vestibular da USP, um feliz acaso me pôs nas mãos Guerra em Surdina, que a Civilização Brasileira tinha lançado em 64 e que foi recentemente republicado. Minha empatia com o livro foi imediata. Em 68, no Brasil da ditadura militar, um momento de grande efervescência política, e não só no país, eu ensaiava uma participação mais direta nos movimentos de oposição ao regime, através das lutas estudantis. Em Guerra em Surdina contava-se a história de João Afonso que, com outros jovens brasileiros, haviam sido convocados em 44 pelo Ministério da Guerra para servirem ao lado dos aliados na Campanha da Itália. João Afonso aparecia como fio condutor de uma reflexão que, entre outras coisas, incidia sobre o absurdo de uma guerra feita em nome da democracia, quando no Brasil se vivia a ditadura do Estado Novo. Da mesma forma como a ditadura militar instalada em 64 prendia e torturava opositores, em nome da preservação da democracia contra o chamado "perigo vermelho". Para mim foi impossível ler o livro sem fazer paralelos, a cada passo, com o que então eu via e vivia. Tomo como único exemplo uma das reflexões de João Afonso:

...eu via que jovens estavam lutando para modificar semelhante estado de coisas. Tive colegas presos e torturados. [...] Eu tinha a noção de que estava tudo errado, mas já me acostumara a dominar a sensibilidade, que é um perigo em tempo de ditadura. Indo à Polícia central tratar de algum assunto de rotina, podiam-se ouvir os gritos dos supliciados, pois a ferocidade do regime chegara a ponto de dispensar disfarces. [...] Naturalmente não se passa impune por uma experiência dessas. A aceitação do mundo assume então um cunho de covardia, de aviltamento.

Eram tantas as semelhanças com minha própria experiência que a identificação foi imediata. Havia uma preocupação ética que marcava o livro do começo ao fim e que deixava ver com muita clareza a importância 
atribuída pelo autor à consciência dos valores humanos dos quais não se pode, em nenhuma hipótese, abrir mão. Naquele momento, em 68, eu ainda não sabia que seria justamente essa aguda consciência da necessidade de preservação da dignidade, principalmente em períodos difíceis como o que se vivia, um dos traços que mais me impressionariam, desde o início, na figura do professor Boris, que vim a conhecer em 69, quando entrei no curso de Russo da USP.

Outro traço com o qual também me identifiquei de imediato foi o do Mestre dedicado à tarefa de colocar os alunos em contato com o que de mais importante há na cultura, enquanto meio de humanização, introduzindo-os no que de melhor produziu a tão rica literatura russa. $\mathrm{E}$ ao mesmo tempo abrindo-lhes caminho para o que de mais significativo havia sido feito e se fazia, em termos de reflexão crítica sobre a literatura, tanto na Rússia como no Brasil. Em suas aulas, a abordagem das obras se fazia através de um rigoroso trabalho de tradução, uma das muitas facetas da inestimável contribuição que o Mestre desde antes fazia e continuaria fazendo ao Brasil, ampliando nosso acesso à literatura russa através de traduções de altíssima qualidade.

Se insisto em sublinhar a palavra Mestre ao referi-la a Boris Schnaiderman é também para salientar nele dois atributos que, entre nós, não é comum se encontrarem na mesma pessoa, e que entendo fazerem parte constitutiva da condição de Mestre. Por um lado, o incansável espírito de pesquisa a se colocar sempre novas questões. Por outro, a socialização das descobertas, através do exercício da docência como atividade tão substantiva e importante quanto a de pesquisa.

Manifestava-se de vários modos a preocupação desse Mestre com dar o melhor aos alunos. A começar do rigor com que corrigia os trabalhos, passo a passo, com riqueza de comentários que finalizavam sempre com alguma palavra calorosa de incentivo. Lembro-me até hoje de um trabalho ao qual eu havia me dedicado muito, mas que entregara sem a necessária revisão final, e que me foi devolvido com um bilhetinho que dizia: " $\mathrm{O}$ raciocínio crítico é excelente, surpresa agradável a todo professor. Mas você precisa afinar melhor seu violino".

Foi ainda a preocupação com os alunos que o levou, certa vez, a complementar as atividades de sala de aula, em que se traduziam alguns dos mais importantes poetas russos de vanguarda, com a presença de Haroldo de Campos que nos mostrou, com riqueza de detalhes, como havia sido a parceria com Schnaiderman na tradução transcriadora desses poetas. Lembro-me de que era tão grande o cuidado de avaliar todas as consequências de cada uma das escolhas tradutológicas que não pude deixar de comparar aquela atividade com um trabalho de ourivesaria. Trabalho ao qual se deve o livro Poesia Russa Moderna, cuja $1^{a}$ edição saíra em 68 pela Civilização Brasileira. E cuja $6^{a}$ edição saiu pela Perspectiva em 
2001, o que mostra que se tornou entre nós uma antologia clássica sobre a poesia russa do período.

Foi nas aulas de literatura russa que tomei contato com os estudos de linguística e poética feitos por aqueles que o Prof. Boris trata como os "assim chamados" formalistas russos. E aqui retomo a expressão que está no prefácio à Teoria da literatura dos formalistas russos, publicada pela Globo, de Porto Alegre, em 71. E também no livro posterior, Turbilhão e semente, que é de 83 , de novo há referência à "corrente de crítica literária tão erradamente chamada Formalismo Russo". O professor insistia em que, para além dos exageros de algumas formulações com que esses estudiosos procuravam marcar posição contra a velha estética, seria preciso considerar sua contribuição efetiva à abordagem do fenômeno literário. E aqui Schnaiderman é claro:

"quando se estuda em pormenor a contribuição dos formalistas russos, percebe-se desde o início uma tendência marcada a levar em conta a relação dialética entre sincronia e diacronia, a ver a língua como um fenômeno social e, como tal, relacionada com as demais 'séries sociais', e sobretudo uma acentuada importância atribuída ao estudo histórico tanto da linguagem como da sua expressão literária".

Assim, desde aquela época, o professor chamava nossa atenção para o equívoco das referências, que eu diria até hoje comuns entre nós, àqueles estudiosos como "formalistas", dando-se ao termo uma conotação negativa. E volto a citar porque me parece que é ainda importante chamar a atenção para o problema:

Os clichês então surgidos continuam atuando às vezes até hoje, no sentido de uma condenação vaga do movimento, sem que se tenha uma noção exata do que ele significou. Basta ver, neste sentido, a imprecisão com que alguns críticos lukacsianos se referem ao 'formalismo', como se o termo designasse algo vergonhoso ou assustador".

Lembro-me também de que foi graças ao Professor Boris que os que estudávamos russo naquela época viemos a conhecer a obra de Mikhail Bakhtin, muito antes que esse grande teórico viesse a ocupar, entre nós, o lugar de merecido destaque que é o seu hoje. No já mencionado livro Turbilhão e semente, onde o professor relata o encontro pessoal com o teórico russo, pude reencontrar, ao lado do estudioso de Bakhtin e Dostoievski, o ficcionista que, mesmo se dedicando ao trabalho crítico, não deixava de marcar seu estilo com calor e com sabor, optando, por exemplo (e este é só um pequeno exemplo), por chamar de "Conversa" o que a linguagem acadêmica chamaria de "Introdução".

A propósito, quando no início tracei uma linha nítida entre o ficcionista e o professor, incorri num erro que é o próprio Mestre a corrigir. Em seu livro Projeções: Rússia/Brasil/Itália, publicado em 78 pela 
Perspectiva, ele procura esclarecer o motivo da escolha do termo "projeções", do título. Diz que assim lhe foi possível expressar "um mundo em que tudo se projeta contra tudo, onde não há limites precisos entre coisa alguma, o reino do deliquescente e do jamais acabado, da fluidez e do infindável". Com isso em vista, corrijo meu erro de início, uma vez que o escritor Boris Schnaiderman assume plenamente sua condição múltipla e sua pertença a um dado momento histórico. Trata-se de alguém que é ao mesmo tempo ficcionista, pesquisador, professor, crítico, tradutor, jornalista e todos integrados por um estilo que, mesmo nos momentos de maior concentração na reflexão teórica, nunca se enrijece em tecnicismos, nunca perde aquela dimensão coloquial que tanto cativa o leitor. Sobretudo, um estilo que põe à mostra, o tempo todo, um espírito de questionamento incansável, para o qual o final de um movimento reflexivo é sempre uma pergunta que suscita nova reflexão.

Disso eu poderia citar mais de um exemplo. Mas me chama particularmente a atenção um livro mais recente, Os escombros e o mito, publicado em 97. Livro fundamental para qualquer um que queira ter uma visão panorâmica do que é a Rússia, hoje, após o fim da União Soviética. Aí se encontra um balanço da situação atual daquele país, nos mais diversos âmbitos da cultura: jornalismo, literatura, historiografia, os estudos de semiótica, linguística, teoria literária, folclore, mito, filosofia, religião, as artes plásticas, fotografia, teatro, cinema, música. Chama a atenção a preocupação do autor com compreender a realidade retratada em toda a vitalidade das contradições que a constituem. Um momento particularmente significativo, nesse sentido, é aquele em que a figura de Lênin aparece, primeiro, envolvida nas tintas negras dos massacres efetivados graças a ordens suas. Mas o autor, assim como é cuidadoso ao citar as fontes que lhe permitem mostrar tais fatos, também o é ao apontar o oposto. Assim, dá notícia sobre um inédito de Pasternak, escrito quando O doutor Jivago já se encontrava quase concluído. Se nesse romance há uma visão decepcionada da revolução e da guerra civil, aquele inédito funciona como uma espécie de "contracanto", no dizer de Schnaiderman. Aí, a figura de Lênin aparece através da "retidão, que saltava aos olhos"; da "ousadia sem precedentes de sua comunicação com a fúria desencadeada do elemento popular"; da "capacidade de não levar em conta nada, [...] em prol da criação de um mundo novo". Como disse antes, essa preocupação com retratar as várias faces da realidade vai de par com a de nunca dar por concluída a busca da verdade. Não é por outro motivo que o livro termina com muita perplexidade e por uma pergunta:

Seria possível? Era o mesmo povo? Como se pode passar com tanta rapidez do sublime ao mais ignóbil e repulsivo? Por mais que leiamos o nosso Dostoievski, o nosso Tolstói, o contraste entre a tróica de Gogol e os abismos 
de abjeção, de ignomínia que a história nos desvela, só pode causar-nos perplexidade e horror. [...] O tropel da história se confundirá um dia com a corrida desabalada da tróica de Gogol?".

Nos momentos finais de Guerra em Surdina, há um vertiginoso mergulho na consciência de João Afonso, vertigem que espelha o momento particularmente difícil de fim do conflito, quando os limites são nebulosos, quando a vida está em suspenso e é muito difícil saber o que se pode esperar do futuro. Tentando entender seu estado de alma tão caótico como o que vê a sua volta, João Afonso fala várias vezes em "turbilhão". O termo comparece repetidamente nesse longo fluir da consciência da personagem. É assim, por exemplo, que ele nomeia a guerra e seu potencial de horror e destruição, sua capacidade de envolver a tudo e a todos num movimento frenético em que a dimensão individual fica muito fragilizada, em que a consciência ética e suas exigências parecem perder o chão onde se sustentar. Num momento particularmente angustiante, ele revê a cena de desolação a que se reduzira um vilarejo recém bombardeado por seu próprio destacamento. Aí aparecem

"as casinhas completamente esfareladas, meu Deus, meu Deus, estão aí as casinhas que eu marcava com um alfinete sobre a carta, foi praí que eu calculei tiro, mas não era eu, o ato de guerra é impessoal, posso arrancar os olhos de alguém, e não terei sido eu o autor do feito, [...] e ademais há o turbilhão, tudo o que eu fizer nesse turbilhão será obra de um outro...".

Entretanto, adiante, esse mesmo "turbilhão" começa a trazer em si os prenúncios de retorno à vida, quando João Afonso compartilha com outros soldados da "grande mesa de madeira" de uma cantina improvisada "no porão de uma das casas, as paredes claras, os barris enormes, os copázios de vino rosso, espumante e perturbador, tudo isso reforça o turbilhão em que vivo, acrescentando às minhas sinistras visões, um toque de paz, alegria, ingenuidade e bem-estar". E o narrador conclui: “ O abatimento, a alegria, a bebedeira de João Afonso, tudo se mistura num último rodopio do turbilhão".

No livro Turbilhão e semente, a expressão-título indica "um acontecimento extraordinário da literatura, o turbilhão e semente que foi Dostoievski, o terremoto por ele provocado no romance que expressava o determinismo causal típico do século XIX". Diante disso, a gente se pergunta: que força tem essa palavra "turbilhão", que tanto frequenta a obra? Que sinaliza um movimento vertiginoso que nada deixa quieto e que ultrapassa o plano do eu consciente, apontando para um envolvimento com a vida em sentido mais amplo, no que ela tem de contraditório, desestabilizador e, por isso, também, criador. Não será que o que ela designa deita raízes tão fundas na experiência daquele que a usa que acaba sendo a expressão de uma verdade originária, impossível de ocultar? 
Afinal, não terá sido também movida por um turbilhão, que espalhou muita semente, essa vida que deu tantos e tão diversos frutos? À qual devemos não só um conjunto vasto de livros, dos quais citei apenas alguns. Essa vida a cuja fecundidade devemos a presença que têm hoje no Brasil a cultura e literatura russas. À qual devemos a criação do curso de Russo da Universidade de São Paulo, curso que vem crescendo e se impondo, pela seriedade, competência e capacidade multiplicadora de seus professores e pesquisadores. E tudo isso devemos ao turbilhão Boris Schnaiderman.

Obrigada, Mestre. 